\title{
Прилади та устаткування
}

Мікульонок І.О., докт. техн. наук

Національний технічний університет Украӥни «Київський політехнічний інститут імені Ігоря Сікорського», Київ

nросn. Перемоги, 37,03056 Kuїв, e-mail: i.mikulionok@kpi.ua

\section{Використання полімерів та пластмас у теплообмінному обладнанні (Огляд)}

Розглянуто можливість використання теплообмінників, повністю або частково виготовлених із застосування полімерів та пластичних мас. Незважаючи на очевидну, на перший погляд, недоцільність застосування полімерних матеріалів у теплообмінному обладнанні (низький коефіцієнт теплопровідності, а також невисокі, порівняно з металами, характеристики міцності більшості найпоширеніших полімерів), «полімерні» теплообмінники все впевненіше знаходять застосування у різноманітних галузях промисловості. Запропоновано класифікацію теплообмінних апаратів, конструктивні елементи яких виконано із застосування полімерних матеріалів. У ки: вид полімеру, тип полімерного матеріалу, тип теплообмінного апарата (форма теплообмінних елементів), ступінь використання полімерних матеріалів у конструкції, ступінь рухомості полімерних теплообмінних елементів, рівень складання конструкції, діаметр трубчастих елементів. Виконано критичний аналіз найбільш характерних конструкцій, розроблених вітчизняними й закордонними проектувальниками й винахідниками. Бібл. 21, рис. 13.

Ключові слова: теплообмінний апарат, полімер, пластмаса, класифікація, конструкція.

Теплообмінні апарати є одним з основних видів обладнання хімічної, нафтохімічної, нафтопереробної, харчової та інших галузей промисловості, а також теплоенергетики й систем кондиціонування повітря [1-4]. Традиційними матеріалами для виготовлення елементів теплообмінників (передусім теплообмінних елементів: труб, пластин, блоків) є метали та їхні сплави, а також графіт $[1,5,6]$. У разі використання в конструкціях теплообмінних апаратів елементів, виготовлених з вуглецевої стали звичайної якості, для збільшення терміну їх служби іноді застосовують різного роду захисні покриття, зокрема емаль [6].
У той же час розробниками теплообмінного обладнання пропонується апаратура 3 використанням і інших конструкційних матеріалів, зокрема полімерів та пластичних мас [7-9], у тому числі й 3 додаванням вторинної полімерної сировини під час виготовлення зазначеної апаратури [10]. Багато видів сучасних полімерних матеріалів можуть конкурувати з металами й сплавами не тільки 3 точки зору міцності та твердості, температурного діапазону експлуатації та хімічної тривкості, але що не менш важливо - вартості $[2,7-9,11]$.

На перший погляд використання полімерних матеріалів у теплообмінній апаратурі не- 
доцільно, оскільки теплопровідність більшос- ті конструкційних полімерів на три порядки нижча від теплопровідності металів [12-15]. Проте у разі істотного зменшення товщини теплообмінних елементів з полімерних матеріалів (трубок, пластин тощо), а також відсутності на їхніх поверхнях відкладань та забруднень різної природи їх загальний термічний опір стає порівнянним 3 термічним опором металевих теплообмінних елементів аналогічного призначення. При цьому порівняно 3 металевими полімерні матеріали нерідко характеризуються істотними перевагами: низькою густиною, високою гнучкістю й хімічною тривкістю, нетоксичністю тощо.

Зазначене питання вже було порушене автором [16], проте далі наведено більш грунтовний аналіз розробок теплообмінного обладнання із застосуванням полімерних матеріалів.
Мета досліджень - аналіз можливості використання в хімічних, харчових та споріднених 3 ними виробництвах елементів теплообмінного обладнання, виготовлених із застосуванням високомолекулярних сполук: полімерів та еластомерів.

Аналіз конструктивного виконання теплообмінних апаратів 3 використанням полімерних матеріалів дає можливість запропонувати їхню класифікацію за такими ознаками: вид полімеру; тип полімерного матеріалу; тип теплообмінного апарата (форма теплообмінних елементів); ступінь використання полімерних матеріалів у конструкції; ступінь рухомості (жорсткість) полімерних теплообмінних елементів; рівень складання; діаметр трубчастих елементів (рис.1).

За видом полімеру, застосовуваного в конструкціях теплообмінників, розрізняють

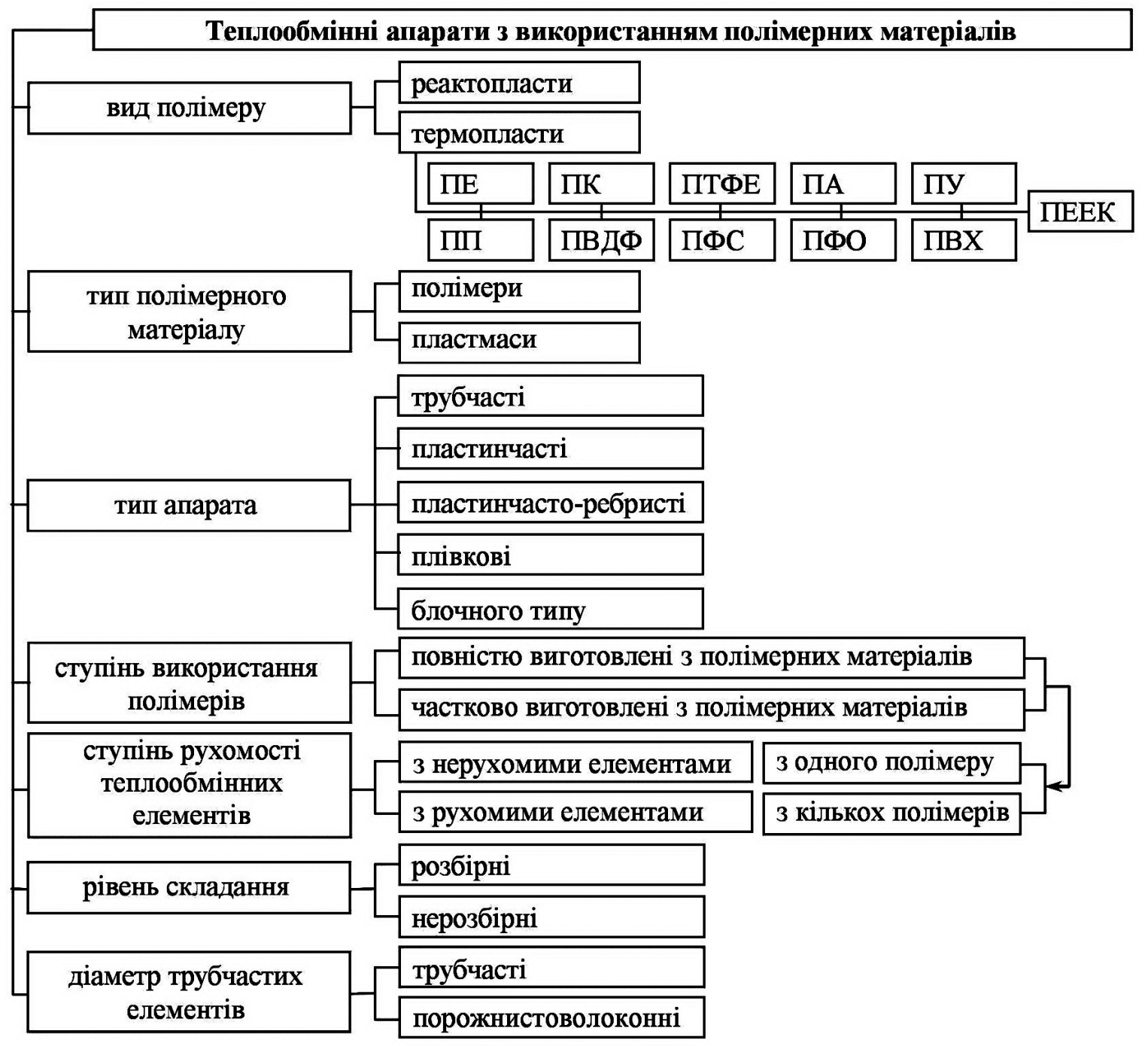

Рис.1. Класифікація теплообмінних апаратів з використанням полімерних матеріалів. 
апарати, виготовлені з використанням як термопластичних, так і термореактивних полімерів.

Найбільшого застосування в конструкціях теплообмінної апаратури знайшли термопластичні полімери. При цьому разом з такими широко поширеними термопластичними полімерами, як поліетилен (ПЕ), поліпропілен (ПП), полікарбонат (ПК), поліамід (ПА), полівінілхлорид (ПВХ) та термопластичний поліуретан (ПУ), використовують полівініліденфторид (ПВДФ), політетрафторетилен (ПТФЕ, тефлон), поліфеніленсульфід (ПФС) та поліфеніленоксид (ПФО), поліефірефіркетон (ПЕЕК) та деякі інші [7].

Поліетилен - найпоширеніший у техніці полімер. Поліетилен нетоксичний, він не змочується водою та іншими полярними розчинниками. Його експлуатаційні властивості зберігаються в широкому діапазоні температур (від мінус 120 до $100{ }^{\circ} \mathrm{C}$ ). Поліетилен є стійким у лужних середовищах будь-яких концентрацій, розчинах нейтральних, кислих та основних солей. До температури $80{ }^{\circ} \mathrm{C}$ він не розчиняється в органічних розчинниках (хоча може трохи набрякати). Також він характеризується достатньо високою міцністю й гнучкістю, а також низькою газо- та паропроникністю.

Поліпропілен більш легкий, твердий, прозорий та термостійкий, ніж поліетилен. Також він характеризується високою міцністю (особливо під час згину). До недоліків поліпропілену можна віднести відносно низьку морозостійкість та схильність до окиснення за підвищених температур.

Полікарбонат є стійким до дії водних розчинів неорганічних та органічних кислот та слабких лугів, води, мастил, рослинних та тваринних жирів, усіх видів харчових продуктів, а також ультрафіолетового та іонізуючого випромінювань. Він нетоксичний, інертний до фізіологічних середовищ, має низьку гігроскопічність. Це теплостійкий, твердий та міцний полімер, що характеризується високою стійкістю до удару, стабільністю властивостей та розмірів у широкому діапазоні температур (від мінус 150 до $200{ }^{\circ} \mathrm{C}$ ).

Поліаміди є стійкими до дії органічних розчинників, проте не можуть протистояти дії основних розчинників, сірчаній й мурашиній кислот. Вони характеризуються високою твердістю й термостійкістю, стійкістю до стирання, дії бактерій та іонізуючого випромінювання.

Полівінілхлорид має достатньо високу механічну міцність, він є стійким до дії лугів будь-яких концентрацій, промислових газів, розчинів солей, бензину, гасу, мастил, жирів, гліцерину, спиртів, гліколів, за температури до
$60{ }^{\circ} \mathrm{C}$ - до дії більшості неорганічних кислот, фізіологічно він абсолютно нешкідливий. Основним його недоліком є термодеструкція під час нагрівання понад $100-140{ }^{\circ} \mathrm{C}$.

Поліуретани (лінійні) стійки до дії води, розведених органічних та мінеральних кислот, мастил, аліфатичних та хлорованих вуглеводнів, а також багатьох окисників. Вони характеризуються високою жорсткістю й малим вологовбиранням.

Полівініліденфторид характеризується високою механічною міцністю, зносо- й атмосферостійкістю, стійкістю до радіоактивного випромінювання, дії мінеральних кислот (за винятком сірчаної кислоти, що димить), лугів, галогенів та вуглеводнів. За температури до $150{ }^{\circ} \mathrm{C}$ впродовж білыше року з полівініліденфторидом не відбувається жодних змін. Вироби з цього полімеру легко піддаються механічному обробленню.

Політетрафторетилен - найбільш хімічно стійкий з відомих промислових полімерів. Він не горить, до температури $260{ }^{\circ} \mathrm{C}$ не розчиняється в жодному розчиннику, на нього не діють кислоти й луги, сильні окисники та інші агресивні речовини (він не витримує лише дії розплавлених лужних металів, трифтористого хлору й газоподібного фтору). Біологічно політетрафторетилен є нешкідливим.

Поліфеніленсульфід характеризується стійкістю до дії вуглеводнів, спиртів, органічних та мінеральних кислот. Так, випробування ПФС у $85 \%$-й сірчаній кислоті за температури $120{ }^{\circ} \mathrm{C}$ протягом 5000 год показали його абсолютні переваги перед такими визнаними з точки зору хімічної стійкості полімерами, як ПВДФ та ПТФЕ [7, 11].

Поліфеніленоксид стійкий до дії киплячої води, перегрітої пари, мінеральних кислот, лугів та перекису, а також радіоактивного випромінювання. Крім того, на поверхні виробів 3 поліфеніленоксиду не розвиваються мікроорганізми. Він розчиняється в хлорованих та ароматичних вуглеводнях.

Поліефірефіркетон - напівкристалічний термопласт з унікальними фізико-механічними, хімічними та електротехнічними властивостями. Він характеризується високою теплопровідністю й твердістю, низьким коефіцієнтом тертя й високою зносостійкістю, при цьому він зберігає свої властивості за температури до $260{ }^{\circ} \mathrm{C}$, а виготовлені з нього вироби характеризуються стабільністю розмірів.

За типом полімерного матеріалу розрізняють теплообмінники або їхні елементи, виготовлені $з$ полімерів та пластмас. 
Крім вище зазначених «чистих» полімерів, у конструкціях теплообмінної апаратури використовуються й полімерні композиційні матеріали [14].

Наприклад, у пат. № ЕР1450124A2 запропоновано трубу, виготовлену з полімеру з наповнювачем та призначену для розміщення в грунті.

У пат. № RU2044984C1 описано теплообмінну трубу з термопластичного полімеру (вид полімеру не зазначено) 3 розташованими в іï стінці відрізками стрижнів, виконаними у вигляді просоченого термопластичним зв'язуючим пучка паралельних вуглецевих волокон. Торці зазначених стрижнів розташовано врівень із зовнішньої й внутрішньої поверхнями труби. При цьому теплопередача між теплоносіями по обидва боки труби здійснюється переважно теплопровідністю через зазначені композиційні стрижні.

У пат. № RU2044985C1 замість композиційних стрижнів використано радіально розташовані композиційні пластини.

У пат. № RU2044986C1 розглянуто аналогічну трубу, при цьому теплопередача між теплоносіями по обидва боки труби здійснюється не через стрижні, а через теплопровідні елементи сітки, що армує трубу. Як термопластичний полімер при цьому було використано полі- сульфон.

У пат. № US6465561B1 описано теплообмінник 3 робочими елементами, виготовленими 3 композиційного матеріалу на основі полімерної матриці й розподілених у ній частинок матеріалу з теплопровідністю вищою за теплопровідність матеріалу матриці (наприклад, частинок вуглецю).

У пат. № CN105973058A та CN202734625U описано теплообмінні труби з поліпропілену 3 наповнювачем із графіту, які характеризуються високою міцністю, корозійною стійкістю й теплопровідністю.

У пат. № JPH0359400А як наповнювач матеріалу труби використано керамічний порошок або волокна (частка наповнювача в композиції від 1 до 50 \% (мас.)). Пропонована труба характеризується високою термічною й корозійною стійкістю.

Труба, згідно з пат. № JPH0436597А, виготовлена $з$ фторполімеру з наповнювачем у вигляді вусів карбіду кремнію, характеризується високою міцністю й теплопровідністю. Аналогічну трубу, але з вуглецевим волокнистим та дисперсним наповнювачем, описано в пат. № JPS63194195A, а в пат. № US5211220A 3 наповнювачем у вигляді вуглецевих волокон.

Теплообмінна труба, у пат. № JPH10132492A, виготовлена 3 вуглецевого волокна, просоченого термореактивним зв'язуючим, характеризується високою міцністю, легкістю, а також термічною й хімічною стійкістю.

\section{За типом теплообмінного апарата}

(формою теплообмінних елементів) розрізняють трубчасті (типу «труба в трубі», кожухотрубні та ін.), пластинчасті, пластинчасто-ребристі (матричні), плівкові й блочні теплообмінники.

Запропонований в а. с. № SU1447040A1 трубчастий теплообмінник містить два пакети теплообмінних труб, кожний з яких виконано за методом лиття полімерів під тиском за одне ціле із трубними дошками. Теплообмінник призначено для зниження температури охолодної рідини двигуна внутрішнього згоряння, яка циркулює в міжтрубному просторі.

Аналогічне технічне рішення запропоновано в а. с. № SU1270533A1, однак теплообмінні труби цього теплообмінника виконано конічними, що не тільки підвищує ефективність теплопередачі, але й полегшує складання теплообмінника.

B a. с. № SU877313A1 також розглянуто конструкцію трубчастого теплообмінника для охолодження води й мастила у двигунах внутрішнього згоряння. Особливістю теплообмінних труб цього апарата є виготовлення їх з електропровідної полімерної композиції, що, на думку винахідників, підвищує процес теплопередачі.

B a. с. № SU958830A1 запропоновано теплообмінник з пучком тонкостінних полімерних трубок, розташованих між стрижнями, які надають трубкам зигзагоподібної форми, що інтенсифікує процес теплопередачі.

Конструкцію трубчастого теплообмінника 3 вертикальними рядами горизонтальних полімерних трубок, виготовлених 3 найрізноманітніших полімерів, переважно 3 поліолефінів розглянуто у заявці № $\mathrm{WO} 00 / 43722 \mathrm{~A} 1$, пат. № US6364008B1 та EP1147356A1. Кожний вертикальний ряд трубок складено з окремих груп, що утворюють своєрідний зигзаг. Таке розташування трубок істотно підвищує ефективність теплообміну з боку зовнішньої поверхні теплообмінних трубок. Трубки мають такі розміри: зовнішній діаметр - 3,8-6,4 мм; мінімальний внутрішній діаметр - 0,76-1,50 мм; товщина стінки $-0,13-0,38$ мм.

Аналогічні гнучкі полімерні трубки використані й у конструкції теплообмінника за заявкою № WO00/53992A1. Проте зазначені трубки мають не прямолінійну, а хвилясту форму. При цьому сусідні трубки зміщено одна відносно одної на половину кроку хвилі, що забезпечує інтенсивний теплообмін усередині та зовні труб (рис.2). 


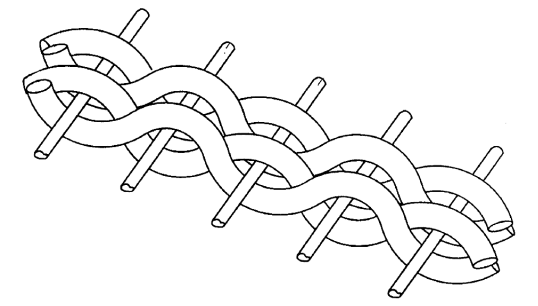

Рис.2. Фрагмент трубного пучка (звявка № WO00/53992А1).

Конструкцію кожухотрубного теплообмінника 3 теплообмінними трубами 3 ПТФЕ розглянуто у заявці № WO02/44641A1 та пат. № CN1297133А. Кінці зазначених труб розвальцьовані й затиснуті між основними трубними решітками й захисною трубною дошкою, розташованою з боку відповідної кришки апарата. При цьому отвори трубної дошки не призначені для закріплення теплообмінних труб, а використовуються лише як їх вхідні (вихідні) ділянки.

У заявці № WO92/19900 A1 та пат. № ЕР0537319А1 запропоновано круглу полімерну трубу з безперервними або дискретними виступами, розташованими на її внутрішній поверхні по гвинтовій лінії.

Полімерну трубу з пластифікованого ПВХ із поздовжніми ребрами, призначену для змійовикового теплообмінника типу «труба в трубі» описано в а. с. № SU400796A1. Аналогічну трубу з ПВХ із поздовжніми ребрами запропоновано в а. с. № SU1343234A1.

У заявці № WO98/11398A1 та пат. № ЕР0928406А1 розглянуто теплообмінну трубу, виготовлену 3 термопластичного матеріалу на основі поліаміду й призначену для використання в трубчастих теплообмінниках, у заявці № WO2017/102785A1 - теплообмінну трубу 3 термопластичного поліуретану універсального призначення.

В а. с. № SU1139962A1 наведено конструкцію круглої полімерної труби з поздовжніми зигзагоподібними ребрами на її зовнішній поверхні. Зазначені ребра утворюють в осьовому напрямку труби дифузорні й конфузорні ді- лянки, що чергуються між собою (рис.3). При цьому ребра пропонується виконувати 3 полі- мерного матеріалу 3 коефіцієнтом теплопровід- ності вищим за коефіцієнт теплопровідності матеріалу стінок труби.

В a. с. № SU1151808A1 наведено конструкцію теплообмінного апарата 3 вертикальними пучками $\mathrm{W}$-подібних полімерних теплообмінних трубок, занурених у рідкий теплоносій.

У вертикальній трубі теплообмінника, згідно 3 а. с. № SU1270530A1, розміщено поздовжню вставку зіркоподібного профілю, виконану 3 олеофільного (тобто ліофільного у разі мастил та

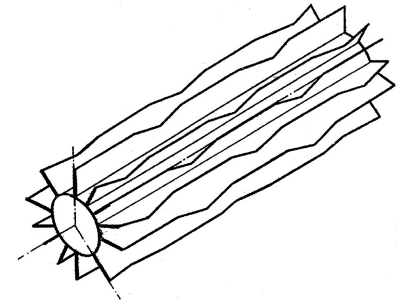

Рис.3. Трубний пучок теплообмінника (а. с. № SU1139962A1).

жирів) матеріалу, зокрема поліетилену. Зазначена вставка зменшує товщину плівки конденсату фреону, що інтенсифікує його конденсацію.

У заявці № WO97/24573A1 та пат. № EР0870160A1 розглянуто кожухотрубний теплообмінник 3 розташованою в міжтрубному просторі гвинтоподібною перегородкою, виготовленою з полімерного матеріалу, переважно поліаміду (рис.4). Зазначена перегородка забезпечує відповідний рух теплоносія в міжтрубному просторі теплобмінника, унеможливлюючи утворення застійних зон.

У пат. № JP2002350090A описано східчасту втулку для фіксації полімерної труби в отворі трубної решітки кожухотрубного теплообмінника.

Полімерний капілярно-пористий трубчастий теплообмінний елемент оригінальної форми запропоновано в заявці № WO2007/012344A1 та пат. № ЕР1907762А1. Зазначений трубчастий елемент зігнуто у вигляді змійовика, зовнішній контур якого утворює компактний паралелепіпед. Використовувати зазначений елемент пропонується в системах кондиціювання повітря.

Теплообмінний вузол аналогічного призначення, але $з$ розташованими в одній площині паралельними прямолінійними полімерними ка пілярно-пористими трубками запропоновано в заявці № WO2007/039395A1 та пат. № EP1938019A1.

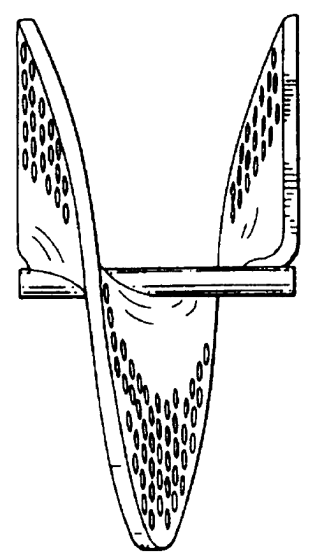

Рис.4. Гвинтова полімерна перегородка міжтрубного простору кожухотрубного теплообмінника за заявкою № WO97/24573A1 та пат. № ЕР0299182А2.. 
Теплообмінник з прямолінійними одно- та багатошаровими трубками для системи «повіт- ря рідина» описано в заявці № WO2013/063359A1 та пат. № ЕР2771637А1. Виготовлені 3 різних полімерів трубки переважно мають діаметр 1-10 мм, товщину стінки 0,1-1,0 мм. Також можливе використання трубок діаметром 0,2-0,5 мм (у цьому разі теплообмінник коректніше віднести до порожнистоволоконних теплообмінних апаратів).

У трубчастому теплообміннику, згідно 3 а. с. № SU1525424A1, гнучкі полімерні теплообмінні трубки попарно переплетено між собою й укладено з утворенням коаксіально розташованих порожнистих циліндрів. Такий трубний пучок знижує гідравлічний опір та ймовірність утворення застійних зон теплоносіїв.

У трубчастому теплообміннику, згідно з а. с. № SU1688106A1, гнучкі полімерні трубки виконано у вигляді спіралей, занурених у рідкий теплоносій, що заповнює гальванічну ванну. Під час руху теплоносія по трубках вони коливаються, що інтенсифікує процес теплообміну.

B a. с. № SU1758380A1 описано горизонтальну поліетиленову трубу з кільцевими гофрами. Недоліком цієї труби є утворення застійних зон у нижній частині гофрів та складність видалення залишків рідкого теплоносія 3 них під час обслуговування й ремонту теплообмінного апарата. Подібну трубу описано у пат. № ЕР1862753A1. При цьому в разі наявності у двошарової гофрованої труби гладкого внутрішнього шару вона позбавлена зазначеного недоліку, властивого одношаровим гофрованим трубам. Також у разі двошарової гофрованої труби значно зростає термічний опір іï стінки, тому таку трубу доцільно використовувати як кожух теплообмінника для зниження теплових втрат у навколишнє середовище [17].

Екструзійний спосіб виготовлення легкої, міцної та гнучкої полімерної труби із внутрішнім турбулізатором описано в пат. № JPS5863421A. Виготовлення полімерних та композиційних труб екструзією є не тільки найбільш універсальним та продуктивним, але й економічним методом $[18,19]$. При цьому з'являється можливість виготовлення полімерних труб з найрізноманітнішими засобами для інтенсифікації теплообміну як з внутрішньої, так і зовнішньої поверхонь [20, 21].

У пат. № DE2013804A1 запропоновано полімерну теплообмінну трубу, що має підвищену міцність внаслідок наявності в її каналі численних перегородок (рис.5). Таке конструктивне рішення дає можливість для певного тиску ви-
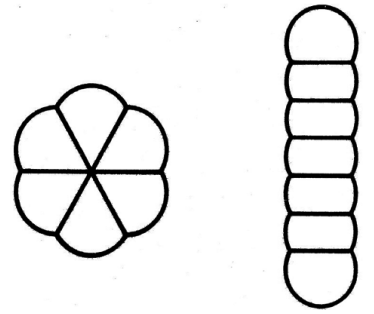

Рис.5. Трубний пучок теплообмінника (пат. № DE2013804A1).

користовувати труби більшого діа- метра або труби з меншою товщиною стінки.

У пат. № DE102010006370A1 розглянуто вертикально розташовану циліндричну полімерну трубку, що кінцевими ділянками закріплена в трубних решітках та в середній частині має температурний компенсатор у вигляді сильфона. Таке конструктивне виконання трубки забезпечує збереження іï прямолінійності під час експлуатації теплообмінника.

У пат. № JPS6431622A розглянуто швидкий та ефективний спосіб закріплення полімерних труб у полімерних трубних решітках за допомогою спеціального кільцевого зварювального інструмента.

У пат № US4323115А описано конструкцію високоміцної трубної решітки 3 полімерного матеріалу.

У пат № JPS6484098A запропоновано конструкцію кожухотрубного теплообмінника 3 $\mathrm{U}$-подібними полімерними гнучкими трубками, що в місці свого вигину огинають спеціальний криволінійний елемент, який запобігає перетиску гнучких трубок.

У пат № CN107747881A розглянуто конструкцію полімерних поперечних перегородок трубного пучка кожухотрубного теплообмінника 3 квадратними отворами для проходу теплообмінних труб. За допомогою зазначених отворів труби не тільки надійно фіксуються стінками отворів перегородок, але й при цьому забезпечується прохід теплоносія крізь кути квадратних отворів, що підвищує ефективність теплообміну.

У пат. № JPH02192932А описано трубний пучок кожухотрубного теплообмінника, у якому трубки проходять крізь зміщені отвори поперечних перегородок трубного пучка, тим самим набуваючи по довжині зигзагоподібної форми, що сприяє інтенсифікації теплопередачі.

Трубчастий теплообмінник оригінальної форми наведено в пат. № GB2017895A. Трубний пучок апарата виконаний у вигляді бухти (котушки) із зазором між сусідніми витками й призначений для занурення в бак з оброблюваним рідким середовищем. 
У пат. № CN203274554U описано модульний теплообмінник із гнучкими полімерними трубами, укладеними у вигляді спіралей в окремі блоки. Перевагою теплообмінника є можливість простого регулювання поверхні теплообміну змінюванням кількості блоків.

У пат. № UA104449U, UA104450U, а. с. № SU1193424A2 розглянуто конструкції пластинчастих теплообмінників-конденсаторів 3 пакетом еластичних пластин, виготовлених 3 високомолекулярної сполуки (вид матеріалу не зазначено). Газовий теплообмінник аналогічної конструкції описаний в а. с № SU577387A1.

У пластинчастому теплообміннику, згідно з a. с № SU1200114A1, між гнучкими полімерними пластинами встановлено паралельні дистанційні спіральні турбулізатори, які деформують пластини з утворенням конфузорно-дифузорних каналів між ними. Така конструкція істотно інтенсифікує процес теплопередачі.

У пластинчастому теплообміннику, згідно 3 a. с. № SU1206603A1, полімерні плівки натягнуто на рамки, що деформуються. У результаті різної деформації рамок відповідні плівки набувають різного натягу 3 утворенням різноманітної форми: від плоскої до хвилеподібної. Це дає змогу змінювати гідродинаміку потоків теплоносіїв, а отже й ефективність теплообміну.

Плоскі еластичні теплообмінні елементи пластинчастого теплообмінника, згідно $3 \mathrm{a.}$ с. № SU1208420A1, виконано з дискретними виступами й западинами, розташованими в шаховому або коридорному порядку.

Теплообмінні елементи у вигляді плоских плівок 3 аліфатичного поліаміду завтовшки 0,12-0,50 мм застосовано в конструкції пластинчастого теплообмінника, описаного в пат. № US4411310A.

У пат. № US5050671А запропоновано конструкцію полімерної панелі пластинчатого теплообмінника. Панель виконано завтовшки 0,37 мм та виготовлено 3 поліаміду, наповненого скловолокном.

Також пластинчасті теплообмінники різного конструктивного виконання наведено в пат. № US5112538A та № US5499676A.

Пластинчасто-ребристий теплообмінний апарат розглянуто в пат. № RU2133936C1 та № US5671804A. Апарат має вигляд триканального вертикального еластичного пакету, виготовленого з полімерної плівки. Між собою пакети розділені пласкою плівкою, при цьому бічні канали утворені плівками, гофрованими в горизонтальному напрямку, центральний канал - плівкою, гофрованою у вертикальному напрямку. У центральний канал подається пара, що піддається конденсації, в бічні канали грійна пара.

Конструкцію повітряно-повітряного пластинчасто-ребристого теплообмінника наведено в пат. № US6145588A (рис.6). При цьому теплообмінні пластини пропонується виготовляти 3 цілої гами різних конструкційних полімерів.

У плівкових теплообмінниках робочою теплообмінною поверхнею є полімерна плівка. Теплообмінні поверхні таких апаратів плівкового типу зазвичай розташовують вертикально, при цьому рідкий теплоносій стікає по них у вигляді гравітаційної плівки (див., наприклад, пат.

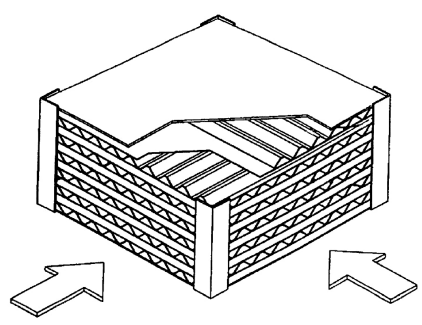

Рис.6. Теплообмінник за пат. № US6145588A.

№№ GB1313300A, GB1153142A, а також а. c. № SU581366A1, SU987361A1, SU1078233A1). У нагрівному радіаторі, згідно 3 а. с. № SU1476268A1, плівкова робоча поверхня призначена для обігріву повітря різних приміщень.

У пат. № EP3193124A1 описано конструкцію теплообмінника блочного типу, у якому полімерний корпус розділено перегородками на розташовані в шаховому порядку паралельні канали різного поперечного перерізу для двох теплоносіїв (рис.7).

За ступенем використання полімерних матеріалів у конструкцї розрізняють апарати, повністю й частково виготовлені 3 полімерних матеріалів.

Перші характеризуються тим, що всі елементи їх конструкції виконано з полімерного матеріалу (одного або декількох видів), а другі - тим, що з полімерного матеріалу (одного або декількох видів) виготовлена лише частина елементів теплообмінників.

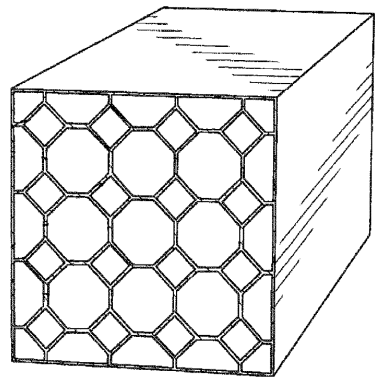

Рис.7. Трубний пучок теплообмінника (пат. № ЕР3193124А1). 
При цьому надалі будемо вважати, що до «полімерних» теплообмінників належить обладнання, мінімум один 3 основних конструктивних елементів якого (теплообмінні елементи, корпус, трубні решітки, кришки, розподільні камери, плити тощо) повністю виготовлені 3 полімерного матеріалу. Тому тут не розглядатимемо конструкції елементів апаратів 3, наприклад, металевою основою, що має полімерне покриття.

До апаратів, повністю виготовлених 3 полімерних матеріалів, можна віднести теплообмінник згідно 3 а. с. № SU1447040A1 (розглянуто раніше).

Виготовлений з поліаміду кожухотрубний теплообмінник описаний у заявці № IL51706A та а. с. № SU743599A3 (рис.8). Особливістю його конструкції є те, що кришки апарата виготовлено цільними разом з патрубками й фланцями. При цьому один з основних недоліків полімерів - низька теплопровідність - у цій конструкції є перевагою, оскільки суттєво знижує теплові втрати з поверхні кришок та кожуха апарата.

Аналогічне технічне рішення запропоновано у пат. № GB2510335A та CN105190219A (для підсилення жорсткості й міцності в стінці кришки може бути розташована металева вставка).

Аналогічне рішення запропоновано в кожухотрубному теплообмінному апараті за заявкою № WO2014/118511A1 та пат. № EP2951523A1, у якому кришку разом із фланцем та патрубками виготовлено з полімеру або полімерного композиційного матеріалу як єдине ціле. Таке конструктивне рішення забезпечує високі технологічні та експлуатаційні характеристики кришки.

У а. с. № SU293491A1 та № SU516894A1 розглянуто конструкції пластинчастих теплообмінників з ПТФЕ, призначених для роботи 3 агресивними середовищами.

Також конструкції й способи виготовлення теплообмінної апаратури 3 полімерних ма-

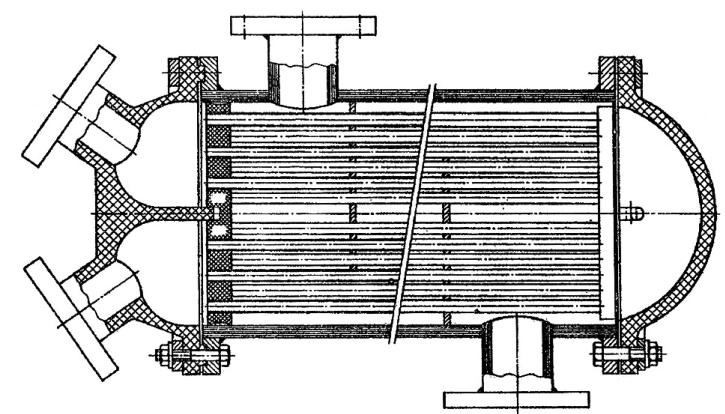

Рис.8. Кожухотрубний теплообмінник (заявка № IL51706A та а. с. № SU743599A3).. теріалів розглянуто в а. с. №№ SU361006A1, SU388900A1, SU542482A3, SU736863A3, SU799631A3, SU914929A1, SU1008609A1, SU1080003A1, SU1211586A1, SU1330445A2, SU1357675A1, SU1368603A1, SU1426468A3, SU1638544A1, SU1652789A2, пат. US4411310A, FR2785375A1，JP2005300127A，JPS5697798A, JPS62175597A, DE2702337A1, DE102010000421A1, CN1550747A，CN103890533A，CN107062957A, CN202494359U, CN205642116U, EP0291322A1, заявці № US2015123297A1.

До теплообмінних апаратів, повністю виготовлених 3 полімерного матеріалу (зокрема поліпропілену), умовно можна віднести радіатор для обігріву повітря в приміщеннях різного призначення, згідно 3 пат. № UA102511U. При цьому в зазначеній конструкції нагрівання теплоносія-повітря здійснюється не крізь стінку іншим теплоносієм, а за допомогою конвективного й радіаційного теплообміну від електронагрівників.

У пат. № RU2008605C1 розглянуто конструкцію теплообмінного апарата, виготовленого 3 полімерного матеріалу частково: його полімерні труби (політетрафторетилен) закріплені в металевих трубних решітках. Перевагою цього апарата є роз'ємне закріплення труб в отворах трубних решіток за допомогою пружного елемента, наприклад, тарілчастої пружини.

Шляхи підвищення надійності закріплення полімерних теплообмінних труб в отворах трубних решіток також запропоновані в заявках № KR20040045337A, KR20110016263A та пат. № CN205561620U, EP0299182A2, US4453301A, US4990206A.

У а. с. № SU145599A1 наведено склад на основі епоксидної смоли й кварцового наповнювача для виготовлення трубних решіток кожухотрубного теплообмінника. Також 3 термореактивного полімеру запропоновано виготовляти трубні решітки в пат. № GB1525641A.

У пат. №№ GB1408823A, US4030540A та US4054980A описано конструкцію полімерних трубних решіток кожухотрубного теплообмінника, що складається з окремих прямокутних блоків з отворами під кінці теплообмінних труб. При цьому кожний з блоків виконано 3 двох рознімних половин, сусідні блоки фіксуються між собою за допомогою напрямних штирів та відповідних западин (рис.9).

У пат. № RU2009429C1 розглянуто конструкцію трубної решітки трубчастого теплообмінника, виконаної у вигляді розміщених в одній площині ковпачків для закріплення в них кінців теплообмінних труб, при цьому простір між ковпачками заповнений полімерним ма- 


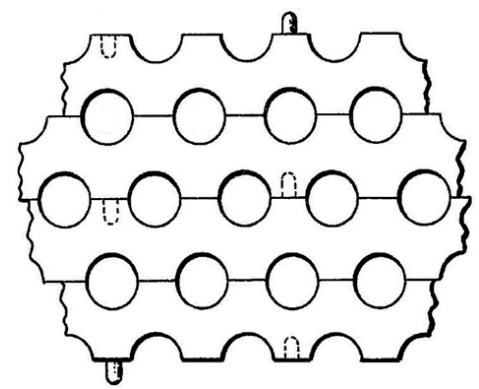

Рис.9. Трубна решітка кожухотрубного теплообмінника за пат. № GB1408823A та US4030540A..

теріалом. Як полімерний заповнювач запропоновано використовувати реактопласт на основі епоксидної смоли.

Трубну решітку 3 полімерного композиційного матеріалу запропоновано також у пат. № RU2044992C1. Зазначена решітка підсилена скловолокнистим просторовим армувальним каркасом, а також наповнювачем 3 вуглецевих волокон, згорнутим навколо отворів для закріплення теплообмінних труб у вигляді циліндричних спіралей та просоченим полімерним зв'язуючим.

Компактні трубні грати з полімерного матеріалу запропоновані у пат. № JPH01256796A та JPH01269519A, а в пат. № US5158729A описано спосіб виготовлення полімерних трубних решіток за методом лиття під тиском.

У пат. № DE4229393A1 розглянуто полімерний кожухотрубний теплообмінник та наведено конструкцію ущільнювального вузла трубної решітки з кришкою та її поздовжніми перегородками. На трубній решітці та/або кришці виконані кільцеві або прямолінійні ущільнювальні канавки 3 поперечним перерізом, що сходиться. У цьому разі виступ кришки або трубної решітки, що входить у відповідну канавку, а також поздовжня перегородка щільно фіксуються в зазначеній канавці.

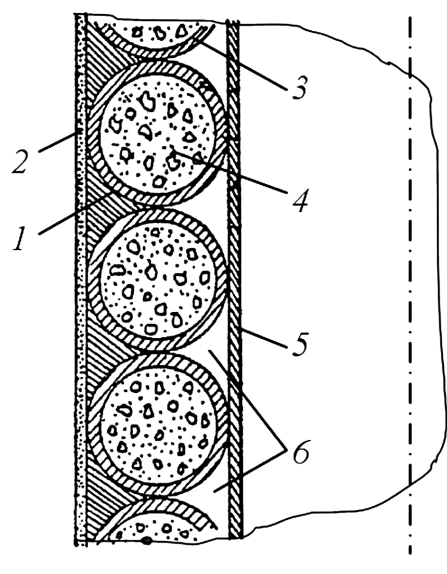

Рис.10. Трубний пучок теплообмінника за заявкою № WO88/09910A1 та пат. № ЕР0299182А2: 1, 4 - спінений еластомерний заповнювач; 2 - зовнішня обичайка; 3 - змійовик із труб; 5 - корпус апарата; 6 - канал для теплоносія
Оригінальну конструкцію ємнісного апарата зі спіральної трубчастою теплообмінною оболонкою наведено в заявці № WO88/09910A1 та пат. № ЕР0424369A1 (рис.10). На зовнішній поверхні циліндричної частини корпуса апарата закріплено трубчастий змійовик, витки якого з'єднані між собою за допомогою зварювання або шару клею чи розділені ущільнювальними прокладками. Із зовнішнього боку змійовика встановлено обичайку, при цьому простір між ними, а також порожнина змійовика заповнені спіненим еластомерним матеріалом (зокрема пінополіуретаном).

Змійовик не тільки утворює в оболонці апарата канал для течії теплоносія (між корпусом апарата та змійовиком), але й значно зміцнює корпус, а також сприяє його теплоізолюванню. Недолік цього технічного рішення необхідність ретельної підготовки теплоносія, що рухається в оболонці апарата, для унеможливлення утворення відкладень.

У пат. № FR2237160A1 описано трубчастий радіатор двигуна внутрішнього згоряння, колектори якого виготовлені з наповненого скловолокном поліфеніленоксиду. Вибір матеріалу колекторів обумовлений необхідністю відповідності коефіцієнтів теплового розширення зазначеного матеріалу й металевих деталей апарата. У пат. №№ FR2479961A3, FR2614980A1 та DE2749205A1 також пропонуються конструкції полімерних колекторів трубчастих автомобільних радіаторів, у пат. №№ FR2793010A1, FR2793010A1, JP2000329482A - полімерні теплообмінні труби трубчастих автомобільних радіаторів.

Конструкцію трубного пучка полімерного трубчастого теплообмінника із зігнутими по довжині трубками наведено в пат. № DE10020797A1 (рис.11). Зазначена конструкція значно інтенсифікує процес тепловіддачі з боку зовнішньої поверхні трубок.

Оригінальну конструкцію трубчастого теплообмінника запропоновано в пат. № GB2077900A. Цей апарат має вигляд гнучкої полімерної трубки, навитої на рознесені по висоті дві рами 3 дистанційними штирями. Пропоноване технічне рішення технологічне й просте в експлуатації.

Ефективну полімерну трубку з дискретними виступами на зовнішній поверхні для використання в трубчастих радіаторах автомобілів описано в пат. № JP2004226056A.

Багатоканальні полімерні труби з розвиненою поверхнею теплообміну запропоновано у пат. № JP2004226057А та № JP2006023034A, у пат. № JP2005313379A - одержувану екстру- 


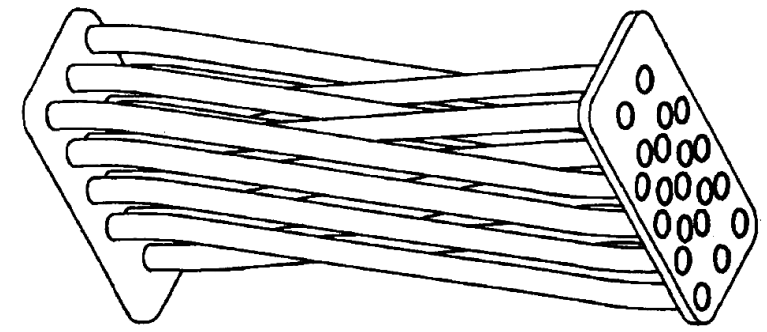

Рис.11. Трубний пучок теплообмінника згідно за пат. № DE10020797A1.

зією полімерну трубу з численними западинами на її зовнішній поверхні.

У пат. №№ FR2356494A1 та JPS6143528A описано способи виготовлення трубних решіток кожухотрубного теплообмінника, що виготовляються з полімерного матеріалу за методом лиття.

Окремі елементи теплообмінників запропоновано також виконувати 3 полімерних матеріалів у заявках №№ US2018/151473A1, US2018/209749A1 та US2018/224211A1, а. с. №№ SU439682A1, SU478467A3, SU653502A2, пат. №o FR2236578A1, FR2494830A1, FR2776371A1, JP2002162175A, JP2003199318A, JP2006078017A, JP2008116196A, JP2011089606A, DE2351529A1, DE2602272A1, DE2657666A1, DE2832961A1, DE4426640A1, DE4433392A1, GB1261905A, GB2049151A, GB2180634A, CN102401606A, CN102706183A, CN105651079A, CN106091739A, CN106767024A, CN202630742U, EP0256913A1, US2240537A, US3270807A, US4190101A.

За ступенем жорсткості (ступенем рухомості) полімерних теплообмінних елементів розрізняють теплообмінники з нерухомою (жорсткою) та рухомою поверхнею теплопередачі.

В апаратах з рухомою теплопередавальною поверхнею їхні теплообмінні елементи часто вібрують або коливаються під впливом потоку одного або обох теплоносіїв, що інтенсифікує процес теплопередачі (наприклад, а. с. № SU1688106A1). У той же час неперервні знакозмінні навантаження, що діють на теплообмінні елементи, згодом можуть призвести до їхнього втомного руйнування.

За рівнем складання розрізняють розбірні й нерозбірні теплообмінні апарати.

Розбірні апарати легко піддаються ремонту й модернізації, але вони складніші у виготовленні та експлуатації, ніж нерозбірні. У свою чергу нерозбірні апарати надійніші в експлуатації, проте вони менш універсальні.

До нерозбірних конструкцій можна віднести теплообмінний апарат (а. с. № SU1447040A1), що розглянуто раніше, а до розбірних - кожу- хотрубний теплообмінник за заявкою № IL51706A.

За діаметром трубчастих елеменmis теплообмінні апарати можна поділити на трубчасті й порожнистоволоконні.

До трубчастих апаратів умовно можна віднести теплообмінники 3 теплообмінними елементами у вигляді труб зовнішнім діаметром до 5 мм включно, а до порожнистоволоконних менш 5 мм.

До порожнистоволоконних теплообмінних апаратів належить конструкція за заявкою WO81/00297A1, пат. №№ US3315740A, US3438434A, US4271900A, EP0032893A1. У цьому апараті кінці гнучких полімерних трубок розташовані в полімерних шайбах, а самі трубки скручені по довжині, що збільшує питому поверхню теплообміну. Всередині волокон рухається перегріта пара, а зовні волокон - вода, що нагрівається. Зовнішній діаметр трубок 3 матеріалу на основі ПТФЕ становить 3,1757,747 мм (рис.12).

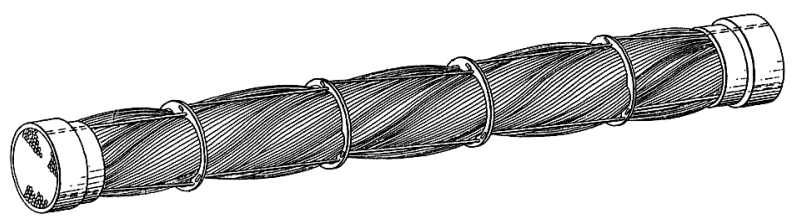

Рис.12. Трубний пучок теплообмінника за заявками № WO81/00297A1 та EP0032893A1.

Одну з перших аналогічних конструкцій подібного кріплення кінців теплообмінних трубок малого діаметра було описано в пат. № GB1130872A фірмою Du Pont (США). При цьому в теплообміннику може бути як два, так і один вузол кріплення трубок (в останньому випадку у відповідному вузлі закріплено обидва кінці U-подібних трубок).

Подібну конструкцію пучка описано також у пат. № GB1237389A, проте в цьому теплообміннику між окремими трубками розташований ниткоподібний елемент, завдяки якому між трубками утворюються канали для проходу теплоносія міжтрубного простору. Подібне рішення, але для пучка не циліндричної форми, а у вигляді паралелепіпеда наведене в пат. № GB1242394A.

Трубчастий теплообмінник з трубками 0,13,0 мм описано в пат. № CN102200399A та № CN202119292U. Два пучки трубок для холодного й гарячого теплоносіїв контактують один 3 одним через проміжну пластину (рис.13). 


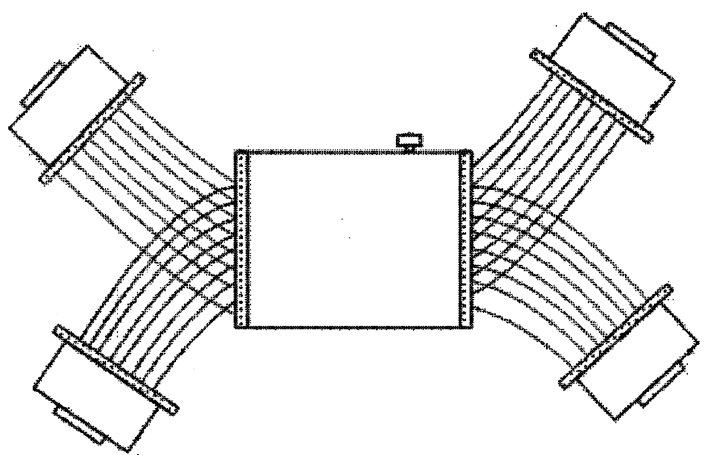

Рис.13. Теплообмінник за пат. № CN102200399A та № CN202119292U.

Теплообмінну полімерну трубку постійного зовнішнього діаметра до 5 мм та змінного внутрішнього діаметра запропоновано в пат. № DE102006004828A1. Товщину стінки зазначеної трубки в місці їі кріплення до колектора теплообмінника виконано більшою, ніж у іï середній частині (відповідно поперечний переріз каналу трубки на її кінцевих ділянках менше).

\section{Висновки}

Розглянуто та запропоновано класифікацію теплообмінних апаратів, у конструкції яких тією чи іншою мірою використано різноманітні полімерні матеріали. Як видно 3 результатів проведених досліджень, кількість типорозмірів «полімерного» теплообмінного обладнання невпинно зростає. При цьому розробка нових конструкцій відповідного обладнання значно полегшується завдяки створенню нових конструкційних полімерних композиційних матеріалів, а також значним можливостям числового моделювання, що дає можливість на етапі дослідження та проектування теплообмінників істотно скоротити обсяг тривалих та накладних фізичних експериментів або навіть повністю відмовитися від них.

\section{Список літератури}

1. Справочник по теплообменникам / Под ред. Б.С. Петухова, В.К.Шикова. Москва : Энергоатомиздат, 1987. $912 \mathrm{c.}$

2. Тимонин А.С. Основы конструирования и расчета химико-технологического и природоохранного оборудования. В 3-х т. Калуга : Изд-во Н. Бочкаревой, 2002. 2848 с.

3. Корнієнко Я.М., Лукач Ю.Ю., Мікульонок І.О. та ін. Процеси та обладнання хімічної технології. Київ : НТУУ «КПІ», 2011. 716 с.

4. Мікульонок I.О. Механічні, гідромеханічні і масообмінні процеси та обладнання хімічної технології. Київ : НТУУ «КПІ», 2014. 340 с.
5. Shah R.K. Advances in Science and Technology of Compact Heat Exchangers. Heat Transfer Engineering. 2006. Vol. 27, № 5. P. 3-12. doi: $10.1080 / 01457630600559462$.

6. Мікульонок І.О. Виготовлення, монтаж та експлуатація обладнання хімічних виробництв. Київ : НТУУ «КПІ», 2010. 412 c.

7. Zaheed L., Jachuck R.J.J. Review of polymer compact heat exchangers, with special emphasis on a polymer film unit. Applied Thermal Engineering. 2004. Vol. 24, № 16. P. 2323-2358. doi:10.1016/ j.applthermaleng.2004.03.018.

8. Mikulionok I.O. Classification of tube-in-tube heat-transfer devices (Survey of Patents). Chemical and Petroleum Engineering. 2019. Vol. 55, № 7-8. P. 601-607. doi: 10.1007/s10556-019-00667-w.

9. Bar-Cohen A., Rodgers P., Cevallos J.G. Application of thermally enhanced thermoplastics to seawater-cooled liquid-liquid heat exchangers. 5th European Thermal-Sciences Conference (18-22 may 2008). The Netherlands, Eindhoven, 2008. 12 p. http: / / citeseerx.ist.psu.edu / viewdoc / download? $\mathrm{doi}=10 \cdot 1 \cdot 1 \cdot 456.2756 \&$ rep $=$ rep $1 \&$ type $=$ pdf

10. Mikulionok I.O. Pretreatment of Recycled Polymer Raw Material. Russian Journal of Applied Chemistry. 2011. Vol. 83, № 6. P. 1105-1113. doi: $10.1134 / \mathrm{S} 1070427211060371$.

11. Мікульонок I.О. Технологічні основи перероблення полімерних матеріалів. Київ : Політехніка, 2017. $324 \mathrm{c}$.

12. Физические величины : Справ. / Под ред. И.С. Григорьева, Е 3.Мейлихова. Москва : Энергоатомиздат, 1991. $1232 \mathrm{c}$.

13. Chung D.D.L. Composite Materials: Science and Applications. London : Springler Verlag London Limited, 2010. 349 p.

14. Микулёнок И.О. Классификация термопластических композиционных материалов и их наполнителей. Пластические массы. 2012. № 9. С. 29-38.

15. Mikulenok I.O. Determining the thermophysical properties of thermoplastic composite materials. International Polymer Science and Technology. 2013. Vol. 40, № 9. P. 23-28.

16. Mikulionok I.O. Use of Polymer Materials in Heat Exchangers (Review of Patents). Chemical and Petroleum Engineering. 2019. Vol. 55, № 7-8. P. 687-695. doi: 10.1007/s10556-019-00680-z.

17. Voznyuk V.T., Karvatskii A.Ya., Mikulenok I. O. Investigation of the Cooling of Two-Layer Corrugated Polymeric Pipes. Journal of Engineering Physics and Thermophysics. 2013. Vol. 86, № 3. P. 505-510. doi: $10.1007 /$ s10891-013-0861-8

18. Mikulyonok I.O. Equipment for preparing and continuous molding of thermoplastic composites. Chemical and Petroleum Engineering. 2013. Vol. 48, № 11-12. P. 658-661. doi: $10.1007 / \mathrm{s} 10556-013-$ 9676-x

19. Mikulionok I.O. Classification of Processes and Equipment for Manufacture of Continuous Products from Thermoplastic Materials. Chemical and Petroleum Engineering. 2015. Vol. 51, № 1-2. P. 14-19. doi: $10.1007 / \mathrm{s} 10556-015-9990-6$. 
20. Mikulionok I.O. Removable Vortex Generators of Pressurized Tubular Channels with Round CrossSection (Classification and Survey of Patents). Chemical and Petroleum Engineering. 2019. Vol. 54, № 11-12. P. 842-848. doi: 10.1007/ s10556-019-00560-6.
21. Mikulionok I.O. Classification of Means of Enhancement of Heat Transfer from the Outer Surface of Pipes (Survey of Patents). Chemical and Petroleum Engineering. 2019. Vol. 55, № 5-6. P. 491-499. doi: $10.1007 /$ s10556-019-00651-4.

Надійшла до редакції 03.01.20

\author{
Микулёнок И.О., докт. техн. наук \\ Национальный технический университет Украины «Киевский политехнический \\ институт имени Игоря Сикорского», Киев \\ просп. Победь, 37, 03056 Киев, Украина, e-mail: i.mikulionok@kpi.uа
}

\title{
Использование полимеров и пластмасс в теплообменном оборудовании (Обзор)
}

\begin{abstract}
Рассмотрена возможность использования теплообменников, полностью или частично изготовленных с использованием полимеров и пластических масс. Несмотря на очевидную, на первый взгляд, нецелесообразность использования полимерных материалов в теплообменном оборудовании (низкий коэффициент теплопроводности, а также невысокие, по сравнению с металлами, прочностные характеристики большинства наиболее распространенных полимеров), «полимерные» теплообменники все увереннее находят применение в различных областях промышленности. Предложена классификация теплообменных аппаратов, конструктивные элементы которых выполнены с применением полимерных материалов. В ее основу положены следующие признаки: вид полимера, тип полимерного материала, тип теплообменного аппарата (форма теплообменных элементов), степень использования полимерных материалов в конструкции, степень подвижности полимерных теплообменных элементов, уровень сборки конструкции, диаметр трубчатых элементов. Выполнен критический анализ наиболее характерных конструкций, разработанных отечественными и зарубежными проектировщиками и изобретателями. Библ. 21, рис. 13.
\end{abstract}

Ключевые слова: теплообменный аппарат, полимер, пластмасса, классификация, конструкция.

Mikulionok I.O., Doctor of Technical Sciences

National Technical University of Ukraine «Igor Sikorsky Kyiv Polytechnic Institute», Kyiv

37, Peremohy Ave., 03056 Kyiv,Ukraine, e-mail: i.mikulionok@kpi.ua

\section{Polymers and Plastic Use for the Heat-exchange Equipment (Review)}

The possibility of use of the heat-exchangers in whole or in part manufactured with use of polymers and plastics is considered. Despite obvious, at first sight, inexpediency of use of polymeric materials in the heat-exchange equipment (low coefficient of heat conductivity, and also low, in comparison with metals, the strength properties of the majority of the most widespread polymers), «polymeric» heat-exchangers find application in various areas of the industry more and more surely. Classification of heat-exchange apparatuses which constructive elements are executed with use of polymeric materials is proposed. The following signs are the basis for classification: polymer type, a type of poly- 
meric material, type of the heat-exchange apparatus (a form of heat-exchange elements), reliance on polymeric materials in apparatuses, motion freedom of polymeric heat-exchange elements, level of assembly of a design, and also diameter of tubular elements. Critical analysis the most characteristic designs developed by domestic and foreign designers and inventors is carried out. Ref. 21, Fig. 13.

Key words: heat-exchange apparatus, polymer, plastic, classification, design.

\section{References}

1. Spravochnik po teploobmennikam (1987) [Reference book on heat exchangers]. Ed. B.S.Petukhov, V.K.Shikov. Moscow : Energoatomizdat, 912 p. (Rus.)

2. Timonin A.S. Osnovy konstruirovaniya i raschyeta khimiko-tekhnologicheskogo i prirodookhrannogo oborudovaniya (2002) [Bases of designing and calculation of the chemical and technological and nature protection equipment]. Kaluga : N.Bochkaryovoy Publishing House, 2848 p. (Rus.)

3. Kornienko Ya.M., Lukach Yu.Yu., Mikulionok I.O., Rakytskyi V.L., Riabtsev G.L. (2011). Protsessy ta obladnannia khimichnoi tekhnologii [Processes and equipment of chemical technology]. Kyiv: NTUU «KPI», 716 p. (Ukr.)

4. Mikulionok I.O. (2014). Mekhanichni, hidromekhanichni i masoobminni protsessy ta obladnannia khimichnoi tekhnologii [Mechanical, hydromechanical and mass-exchanged processes and equipment of chemical technology]. Kyiv : NTUU «KPI», 340 p. (Ukr.)

5. Shah R.K. (2006). Advances in Science and Technology of Compact Heat Exchangers. Heat Transfer Engineering, 27 (5), pp. 3-12. doi: 10.1080/ 01457630600559462.

6. Mikulionok I.O. (2010). Vyhotovlennia, montazh ta ekspluatatziia obladnannia khimichnykh vyrobnytztv [Production, installation and operation of the equipment of chemical productions]. Kyiv : NTUU «KPI», 412 p. (Ukr.)

7. Zaheed L., Jachuck R.J.J. (2004). Review of polymer compact heat exchangers, with special emphasis on a polymer film unit. Applied Thermal Engineering, 24 (16), pp. 2323-2358. doi:10.1016/j. applthermaleng.2004.03.018.

8. Mikulionok I.O. (2019). Classification of tube-in-tube heat-transfer devices (Survey of Patents). Chemical and Petroleum Engineering, 55 (7-8), pp. 601-607. doi: 10.1007/s10556-019-00667-w.

9. Bar-Cohen A., Rodgers P., Cevallos J.G. (2008). Application of thermally enhanced thermoplastics to seawater-cooled liquid-liquid heat exchanger. 5th European Thermal-Sciences Conference (18-22 may 2008). The Netherlands, Eindhoven. 12 p. http: / / citeseerx.ist.psu.edu/viewdoc/download doi=10.1.1.456.2756\&rep =rep1\&type $=$ pdf

10. Mikulionok I.O. (2011). Pretreatment of Recycled Polymer Raw Material. Russian Journal of Applied Chemistry, 83 (6), pp. 1105-1113. doi: 10.1134/ S1070427211060371
11. Mikulionok I.O. (2017). Tekhnolohichni osnovy pereroblennia polimernykh materialiv [Technological bases of processing of polymeric materials]. Kyiv : Politekhnika, 324 p. (Ukr.)

12. Fizicheskie velichiny : Spravochnik. (1991). [Physical Quantities : Reference Book]. Ed. I.S.Grigorev, E.Z.Meylikhov. Moscow : Energoatomizdat, 1232 p. (Rus.)

13. Chung D.D.L. (2010). Composite Materials : Science and Applications. London : Springler Verlag London Limited, 349 p.

14. Mikulionok I.O. (2012). Klassifikatziya termoplasticheskikh kompozitzionnykh materialov i ikh napolniteley [Classification of thermoplastic composite materials and their fillers]. Plasticheskie massy, 9, pp. 29-38. (Rus.)

15. Mikulenok I.O. (2013). Determining the thermophysical properties of thermoplastic composite materials. International Polymer Science and Technology, 40 (9), pp. 23-28.

16. Mikulionok I.O. (2019). Use of Polymer Materials in Heat Exchangers (Review of Patents). Chemical and Petroleum Engineering, 55 (7-8), pp. 687-695. doi: 10.1007/s10556-019-00680-z.

17. Voznyuk V.T., Karvatskii A.Ya., Mikulenok I.O. (2013). Investigation of the Cooling of Two-Layer Corrugated Polymeric Pipes. Journal of Engineering Physics and Thermophysics, 86 (3), pp. 505-510. doi: 10.1007/s10891-013-0861-8.

18. Mikulyonok I.O. (2013). Equipment for preparing and continuous molding of thermoplastic composites. Chemical and Petroleum Engineering, 48 (11-12), pp. 658-661. doi: $10.1007 /$ s10556013-9676-x

19. Mikulionok I.O. (2015). Classification of Processes and Equipment for Manufacture of Continuous Products from Thermoplastic Materials. Chemical and Petroleum Engineering, 51 (1-2), pp. 14-19. doi: $10.1007 / \mathrm{s} 10556-015-9990-6$.

20. Mikulionok I.O. (2019). Removable Vortex Generators of Pressurized Tubular Channels with Round Cross-Section (Classification and Survey of Patents). Chemical and Petroleum Engineering, 54 (11-12), pp. 842-848. doi: 10.1007/s10556-019-00560-6.

21. Mikulionok I.O. (2019). Classification of Means of Enhancement of Heat Transfer from the Outer Surface of Pipes (Survey of Patents). Chemical and Petroleum Engineering, 55 (5-6), pp. 491-499. doi: $10.1007 / \mathrm{s} 10556-019-00651-4$.

Received January 3, 2020 